\title{
Lean, Six Sigma and Lean Six Sigma in Higher Education: A Review of Experiences around the World
}

\author{
Sylvie Nadeau \\ Department of Mechanical Engineering, École de technologie supérieure, Montréal, Canada \\ Email: sylvie.nadeau@etsmtl.ca
}

How to cite this paper: Nadeau, S. (2017) Lean, Six Sigma and Lean Six Sigma in Higher Education: A Review of Experiences around the World. American Journal of Industrial and Business Management, 7, 591-603.

https://doi.org/10.4236/ajibm.2017.75044

Received: March 29, 2017

Accepted: May 19, 2017

Published: May 22, 2017

Copyright $\odot 2017$ by author and Scientific Research Publishing Inc. This work is licensed under the Creative Commons Attribution International License (CC BY 4.0).

http://creativecommons.org/licenses/by/4.0/

\begin{abstract}
Economic, demographic, social, technological and political changes worldwide are putting academic institutions under intense pressures. In response, universities are adopting new managerial approaches to their activities: lean, six sigma and lean six sigma. A portrait of this experience emerges from reviewing the literature published over the past decade using the databases Compendex \& INSPEC/Engineering Village and Scopus. These approaches have been applied primarily on a highly localized basis to teaching-related processes or to services such as financing, data processing and building maintenance. Some of the challenges raised are not unknown outside of the university setting. The complexity of universities, the difficulties of interpreting notions such as the client, added value, and the connexions between teaching and research, make the implementation of these approaches difficult. While the few measured results available suggest that they do hold promise, their impact remains to be determined.
\end{abstract}

\section{Keywords}

Lean, Six Sigma, Higher Education, University

\section{Introduction}

The shifting dynamics of the world economy are forcing governments to reexamine the models applied in public administration. Changing demographics are shaking up conventional financing structures in developed nation states. As societies become more knowledge-based, they feel an increasing need to improve access to higher education [1]. Among the consequences of these changes are increased competition among universities [1] for continued funding of operating budgets [2], demands to improve accountability [1] [3] [4] [5] and major (often 
draconian) budget cutbacks [1], often leading to erosion of student-professor interactions and increased sizes of groups filling lecture halls [6] [7], increased workloads for professors and much attrition following retirement of faculty members [6]. Financing of research becomes anaemic, further exacerbating already intense competition between universities [2]. Universities are all soliciting more and more the support of philanthropists (who are also more demanding) to maintain operations, and are increasing or planning to increase tuition fees [6].

Student recruitment is reaching beyond national borders [8] and training is becoming personalized [9]. Universities are perceived as playing a frontline role in the dash towards worldwide mobility of populations: international students often stay in their host countries after graduating, thus contributing to labour force meshing with the alma mater and to the economic growth of their adopted country [1] [10]. Universities are scrambling to diversify their clientele in terms of age, cultural background and prior training [1] and to recruit better students [2] and more qualified professors [8] both locally and internationally, in some cases even encouraging the importation of foreign university programs to national soil [1]. Such internationalization initiatives often heap excessive workloads on faculty members [11].

Technological change and communications occur at such speed that a university education can become quickly obsolete without continued training "delivered on a just-in-time" basis [12]. Meanwhile, students have become better informed and more selective [1] [2]. Virtual or digital university [7] is now a reality, accelerating in its wake a race towards the development of innovative pedagogical methods and materials [7].

The role and responsibilities of a university in a society more and more preoccupied with sustainability are changing [13]. It remains necessary to strive for academic excellence, while "promoting and implementing sustainability practices in teaching, research, community outreach, waste \& energy management and land use" [13]. It goes without saying that universities, be they private or public, have come under tremendous pressure [14].

Literature published in the1990s shows that total quality management (TQM) was the most popular technique in the university community for meeting the challenge of what were then incipient realities, the United States of America being the leader in this type of approach, with faculties of administration and engineering behind most of the initiatives [2] [15] [16]. The popularity of TQM then faded in this community as the lack of clear connexions to the strategic aims of the institutions became apparent [15]. The literature published since the year 2000 reveals a greater interest in contextualisation of lean manufacturing [17] [18] [19].

The aim of this review of the literature is to provide a worldwide portrait of documented experience with the introduction of the lean (waste management focused application of the just-in-time production philosophy), six-sigma (structured improvement management approach focused on an organization's strate- 
gical clients and projects) and lean six sigma (process management and improvement approach based on lean and six sigma) approaches into university communities: the processes and outcomes targeted, the preferred tools, the results obtained, and the challenges and opportunities identified.

The results of our search suggest that there has not been to date (to the best of our knowledge) any conclusive and compelling finding with regard to the use of these new managerial approaches in the university environment in general. Many universities are still on their first experiences with the use of these methods. Although they hold promise, their impact should be interpreted with caution. Immense challenges continue to hinder their successful development.

\section{Methodology}

The literature examined includes peer-reviewed articles (reviews and conference proceedings), monographs and reports published during the years 2000-2016, retrieved using the Compendex \& INSPEC/Engineering Village and Scopus databases. The keywords used (English with French equivalent) were: lean, just in time, agile, university, educational institution, academic, education and higher education. The snowball effect was used to saturate the procedure. The search was focused on titles and abstracts. The articles thus retrieved were read and sorted on the basis of their relevance to the subject under study, their methodological quality and their clarity. More than 110 documents were thus analyzed over a period of about four months.

As proposed previously [1], the results were sorted also into four geographic regions: the Americas (USA, Canada, Mexico), Europe (United Kingdom, Finland), Middle East and Africa (Saudi Arabia, Southern Africa) and Asia Pacific (China, India). These groupings reflect similarities in terms of the drivers of change, be these political, economic or sociocultural as proposed by Brookes and Becket (2007) [1]. The goals of the intervention, and the processes in particular, were divided into two types, namely primary and assistance. Primary processes were separated into operations and tactics. The preferred tools were ranked according to a structure proposed previously [20] for lean six sigma intervention programs in the university environment.

The challenges of introducing and implementing lean, six sigma and lean six sigma were enumerated then divided into two categories, namely characterizing manufacturing settings versus encountered only in academia.

\section{Results}

The lean, six sigma and lean six sigma approaches to management are still emerging in the university setting [21] [22]. Tables 1-3 suggest that American and British universities are the most committed to their implementation. Mexico, Finland, South Africa, India, China and Saudi Arabia universities are involved. The targets of the interventions (Tables 1-3) are mostly primary processes (operational and tactical) associated with the university in its teaching capacity, and supporting processes associated with financial and data processing 
Table 1. Uses of the lean approach in universities.

\begin{tabular}{|c|c|c|c|c|c|}
\hline $\begin{array}{l}\text { Geographical } \\
\text { region }\end{array}$ & References & $\begin{array}{l}\text { Target of the intervention } \\
\text { (processes, outcomes) }\end{array}$ & $\begin{array}{l}\text { Universities/countries } \\
\text { involved }\end{array}$ & $\begin{array}{l}\text { Preferred } \\
\text { tools }\end{array}$ & $\begin{array}{c}\text { Results } \\
\text { documented }\end{array}$ \\
\hline Americas & $\begin{array}{c}{[19][23]} \\
{[24]} \\
{[25]-[31]}\end{array}$ & $\begin{array}{l}\text { Primary processes (operational) } \\
\text { - Student admissions } \\
\text { - Improving course content } \\
\text { - Review of marks } \\
\text { - Service requests by students } \\
\text { at guidance/health centres } \\
\text { - Distribution of bursaries } \\
\text { and financial support } \\
\text { Tactic decisions } \\
\text { - Program improvement } \\
\text { - Hiring of professors } \\
\text { Processes of assistance } \\
\text { - Moving students into } \\
\text { - residences } \\
\text { - Purchasing, payroll, } \\
\text { payment, contractual } \\
\text { agreements for architecture } \\
\text { and engineering services } \\
\text { - Distribution of keys } \\
\text { - Budgetary exercises } \\
\text { Retention of students } \\
\text { Improving information } \\
\text { flow within project courses }\end{array}$ & $\begin{array}{l}\underline{\text { Mexico }} \\
\text { UPAEP U. } \\
\text { USA } \\
\text { Oakland U., } \\
\text { South Dakota } \\
\text { State U., } \\
\text { U. of Central } \\
\text { Oklahoma, } \\
\text { U. of Iowa, } \\
\text { U. of New Orleans, } \\
\text { Bowling Green } \\
\text { State U., } \\
\text { U. of Scranton, } \\
\text { Rensselaer } \\
\text { Polytechnic } \\
\text { Institute, } \\
\text { Old Dominion U., } \\
\text { California } \\
\text { Polytechnic } \\
\text { State U. }\end{array}$ & $\begin{array}{l}\text { Value stream } \\
\text { mapping, } \\
\text { Five why's, } \\
\text { Kaïzen, } \\
\text { Four waste } \\
\text { categories, } \\
\text { Poka-yoke, } \\
\text { Jidoka }\end{array}$ & $\begin{array}{l}\text { Before intervention, } 72 \% \text { of the } \\
\text { undergraduate mark review } \\
\text { process and } 90 \% \text { at the graduate } \\
\text { level was non-value-adding. } \\
\text { The process of student moves into } \\
\text { residences used to take } 4 \text { hours and } \\
\text { now takes } 1.5 \text { hours. } 96 \% \text { of the new } \\
\text { process now includes value-added } \\
\text { activities. } \\
\text { The employee payroll process has } \\
\text { been reduced from } 20 \text { days to } 45 \\
\text { minutes from request to the actual } \\
\text { pay process. } \\
\text { Review of the faculty member } \\
\text { hiring process led to reducing the } \\
\text { number of steps from } 30 \text { to } 25 \text { and } \\
\text { the file processing time by } 54 \% \text {. } \\
\text { Waiting time for a first } \\
\text { appointment at a student service } \\
\text { was } 16 \text { days. } \\
\text { Requests are now processed and } \\
\text { students get an appointment the } \\
\text { same day. } \\
\text { For health services the waiting time } \\
\text { was reduced from } 20 \text { min to } 2 \text { min. } \\
\text { The response times at admissions } \\
\text { passed from } 2 \text { - } 3 \text { weeks to } 1 \text { day. } \\
\text { Before the intervention, } 35 \% \\
\text { of project course management } \\
\text { activity was non-value-adding. } \\
\text { After an electronic platform of } \\
\text { information and document } \\
\text { exchange between students and } \\
\text { professors was set up, these } \\
\text { activities were decreased to } 6 \% \\
\text { a }\end{array}$ \\
\hline Europe & $\begin{array}{c}{[9][21]} \\
{[22]} \\
{[32][33]} \\
{[34]}\end{array}$ & $\begin{array}{l}\text { Primary processes (operational) } \\
\text { - Student admissions } \\
\text { - Delivery of feedback on } \\
\text { student assignments } \\
\text { - Exam rewrites } \\
\text { - Administration of research } \\
\text { financing } \\
\text { - Evaluation of sabbatical } \\
\text { leaves } \\
\text { Tactic decisions } \\
\text { - Program improvement } \\
\text { - Hiring of personnel } \\
\text { - Decision-making by } \\
\text { various committees } \\
\text { Assistance process } \\
\text { - Financial data reports } \\
\text { - Planning of building } \\
\text { maintenance work } \\
\text { - Offering extension programs } \\
\text { - Payroll and employee } \\
\text { payment }\end{array}$ & $\begin{array}{l}\text { United Kingdom } \\
\text { Royal Institute of } \\
\text { Technology, } \\
\text { Cardiff U., } \\
\text { Nottingham } \\
\text { Business School, } \\
\text { Portsmouth } \\
\text { Business School, } \\
\text { U. of St Andrews, } \\
\text { Warwick Business } \\
\text { School } \\
\text { Finland } \\
\text { Turku U. of } \\
\text { Applied Sciences }\end{array}$ & $\begin{array}{l}\text { Rapid } \\
\text { improvement } \\
\text { workshops/events, } \\
\text { Process mapping, } \\
\text { Value stream } \\
\text { mapping, Flow } \\
\text { charts, Written } \\
\text { process cards, Five } \\
\text { why's, Fishbone } \\
\text { diagram, Nominal } \\
\text { grouping } \\
\text { techniques, } \\
\text { Six thinking hats, } \\
\text { Competency } \\
\text { framework, Log } \\
\text { frame matrix, } \\
\text { Visual } \\
\text { management, } \\
\text { Team information } \\
\text { boards, Root cause } \\
\text { analysis }\end{array}$ & \\
\hline
\end{tabular}




\section{Continued}

\begin{tabular}{|c|c|c|c|c|c|}
\hline $\begin{array}{l}\text { Middle East } \\
\text { and Africa }\end{array}$ & [35] [36] & & South Africa & $\begin{array}{l}\text { Value stream } \\
\text { mapping, Root } \\
\text { cause analysis, } \\
\text { Ishikawa } \\
\text { diagramming, } \\
\text { Five why's, Visual } \\
\text { management, } \\
\text { Standard operating } \\
\text { procedure }\end{array}$ & $\begin{array}{l}\text { Management of } \\
\text { a financial aid } \\
\text { service waiting } \\
\text { line reduced from } \\
50 \text { students before } \\
\text { to } 10 \text { after } \\
\text { the intervention. }\end{array}$ \\
\hline Asia Pacific & [37] & $\begin{array}{l}\text { Primary process (operational) } \\
\text { of course content improvement }\end{array}$ & $\underline{\text { India }}$ & & \\
\hline
\end{tabular}

Table 2. Uses of six sigma in universities.

\begin{tabular}{|c|c|c|c|c|}
\hline Geographical region & References & Target of the intervention (processes, outcomes) & Universities/countries involved & Preferred tools \\
\hline Americas & $\begin{array}{l}{[38][39]} \\
{[40][41]}\end{array}$ & $\begin{array}{l}\text { Primary process (operational) of student } \\
\text { admissions; Retention of students; } \\
\text { Graduation }\end{array}$ & $\begin{array}{l}\text { Rose-Hulman Institute } \\
\text { of Technology }\end{array}$ & $\begin{array}{l}\text { Process map, } \\
\text { Statistical analysis, } \\
\text { Ishikawa }\end{array}$ \\
\hline Asia Pacific & $\begin{array}{l}{[42][43]} \\
{[44][45]}\end{array}$ & $\begin{array}{l}\text { Ratio admission/level of placement; } \\
\text { Training quality; Retention of students; } \\
\text { Graduation }\end{array}$ & $\begin{array}{l}\frac{\text { China }}{\underline{\text { India }}} \\
\text { GITAM U. Visakhapatnam } \\
\text { Shri Krishan Institute of } \\
\text { Engineering and Technology }\end{array}$ & \\
\hline
\end{tabular}

Table 3. Uses of lean six sigma in universities.

\begin{tabular}{|c|c|c|c|c|c|}
\hline $\begin{array}{l}\text { Geographical } \\
\text { region }\end{array}$ & References & $\begin{array}{l}\text { Target of the intervention } \\
\text { (processes, outcomes) }\end{array}$ & $\begin{array}{c}\text { Universities/countries } \\
\text { involved }\end{array}$ & Preferred tools & $\begin{array}{c}\text { Results } \\
\text { documented }\end{array}$ \\
\hline Americas & [46] [47] & $\begin{array}{c}\text { Primary process } \\
\text { (operational) } \\
\text { of student admissions }\end{array}$ & $\begin{array}{l}\frac{\text { USA }}{\text { U. of Central }} \\
\text { Florida }\end{array}$ & $\begin{array}{l}\text { Value stream mapping, Process } \\
\text { map, SIPOC (suppliers, inputs, } \\
\text { process, outputs, customers), } \\
\text { Surveys, Critical to quality tree } \\
\text { diagram, Balanced scorecard, } \\
\text { House of quality, Benchmarking, } \\
\text { Statistical data analysis, Fishbone } \\
\text { diagram, Failure mode and } \\
\text { effect analysis, Cost of quality }\end{array}$ & $\begin{array}{l}\text { Cycle time of } \\
\text { application for } \\
\text { admission was } \\
\text { improved, the } \\
\text { target being } 10 \\
\text { working days. }\end{array}$ \\
\hline $\begin{array}{l}\text { Middle } \\
\text { East and } \\
\text { Africa }\end{array}$ & {$[5][48]$} & $\begin{array}{l}\text { Primary processes (operational) } \\
\text { - Improvement of course content } \\
\text { - Distribution of bursaries } \\
\text { and financial aid } \\
\text { - Student graduation logistics } \\
\text { - Welcoming new students } \\
\text { Tactic decisions } \\
\text { - Program improvement } \\
\text { - Welcoming new staff } \\
\text { Process of assistance } \\
\text { - Purchasing payroll/payment } \\
\text { - Management of profiles, data } \\
\text { processing services } \\
\text { - Catering services } \\
\text { - Management of } \\
\text { controlled materials } \\
\text { - Identification of sources } \\
\text { of revenue } \\
\text { Throughput rate }\end{array}$ & $\begin{array}{l}\text { Douth Africa } \\
\underline{\text { Tshwane U. of }} \\
\text { Technology } \\
\text { Saudi Arabia } \\
\text { King Abdullah } \\
\text { U. of Science and } \\
\text { Technology }\end{array}$ & $\begin{array}{l}\text { Organizational diagram, } \\
\text { Project charter, Voice of the } \\
\text { customer, SIPOC, Process modeling, } \\
\text { Critical to Quality Output Measures, } \\
\text { Statistical data analysis, Ishikawa, } \\
\text { Pareto, Scoping frame, Improvement } \\
\text { priority matrix, } 5 \text { why's, } \\
\text { Boxplot, Scatterplot, Risk } \\
\text { assessment, Elevator speech }\end{array}$ & \\
\hline
\end{tabular}


services and building maintenance activities. Processes associated with universities in their research capacity were not examined in detail for the moment. The basic tools (Tables 1-3) are preferred. Very few quantitative measurements of results (Tables 1-3) are documented (e.g. cost/benefit analyses), leading some authors to conclude that much more work is needed before making any claims about what can or cannot be achieved using these approaches [22]. The interventions counted are focused on eliminating wasteful expenditures. As far as we have been able to determine, no study of the impact on occupational health and safety (OHS) following introduction has been documented. The challenges (opportunities) encountered in the university setting and also in the manufacturing sector (in which lean and its derivatives developed) can be summarized as follows:

- Misunderstanding concepts, tools and vocabulary [19] [22] [35];

- Lack of commitment and leadership from upper management [19] [22] [24] [35] [49];

- Deficient commitment and training of staff [17] [19] [22] [46] [49] and students [24];

- Lack of clarity and openness in communications [19] [22] [35] [49];

- Little resources allotted to the interventions [19] [22] [23] [35] [49];

- Poor alignment and matching of interventions with the strategic plan of the organization [19] [22] [35];

- Deficient definition of the problem to be solved [23];

- Insufficient planning, coordination and coherence of the actions and the changes brought to processes [22] [32];

- Resistance to change, inadequate justification, culture of blame, poor management of conflicts within the organization [22] [23] [32];

- Rapidly changing external environment [23]. Challenges that are specific to the university community arise primarily from:

- The complexity of the community and its processes [4] [5] [22];

- Dearth of documented experience in this sector [21] [33];

- Difficulties of contextualizing certain tools in the sector [21];

- Difficulties of defining who the client is and what added value is for the client [22] [25];

- At times deficient links between research and teaching activities [5];

- A negative perception among faculty [26], who feel that its academic freedom is being compromised [32].

\section{Discussion}

Based on the documented experiences of universities attempting to improve the efficiency of their administrative procedures or the overall quality of student education by applying lean, six sigma [50] and lean six sigma [51] methods, it appears safe to say that such an approach is still quite novel in academia. It has yet to be introduced into the university system as a whole, and measured results are limited to a small number of cases. Universities are complex socio-technical 
systems [5] [52], in which multiple processes, goals and priorities are in dynamic, non-linear and often synergic relationships, expectations of several parties must be taken into consideration, and uncertainty affects outcome. The documented experiences concern primarily processes in which such interdependencies are less significant [1], which facilitates appropriation but yields findings that are much more localised [1]. "The primary mission of universities is the production, creation, preservation, transfer and dissemination of knowledge. Their dedication to teaching and research and their service to the surrounding community constitute the common foundation on which they have built the specificity of their sector" (translation of [4]). The processes that have been improved so far are teaching-related; however, there is certainly interdependence between teaching and research, knowledge being the focus of both roles [53]. The literature also reveals that broadening of the applicability of lean manufacturing ideas to other business sectors has advanced [54], that this is a very delicate operation [32] and that the experience of universities is not exceptional in this sense [9] [21]. Some observers nevertheless view the lean method and its derivatives as being suitable for academic institutions and holding much promise for increasing the competitiveness of universities that make a serious commitment to applying them [23]. Like any organisation, a university must deal with uncertainty and with continued change at an ever-increasing pace. It must provide itself with robust tools to perform in an environment fraught with risk and to remain agile in the face of uncertainty. In this age of increasing competition and resource scarcity [55], only those universities that have the wherewithal to distinguish themselves [56] [57] are likely to note a gain in competitive advantage. Will lean, six-sigma and lean six sigma practices be enough to sustain such advantages over the long term? The few conclusive results available do not provide a definite answer to this question for the moment.

The principal obstacle to broader use of these new managerial approaches to improving efficiency is encountered at the step of defining the client and added value [2]. Who is the client of a university? The correct answer to this hard question [7] is crucial for the successful implementation of a lean solution [9] [22]. This has been researched extensively since the first attempts to introduce total quality management in the 1990s [58] and remains the subject of debate [9] [52] [59] [60]. While some researchers state unequivocally that the client is clearly the student (e.g. [14]), others involved in the same intervention within the same institution (private or public) consider the student, parents, industry, donors to the foundation, university, alumni, and society at large to have an equal stake (e.g. [30]), not to mention the granting organisations and institutions that invest directly in research and development in collaboration with the university [2], accreditation organisations, junior colleges or other universities, and professional organisations [23]. It is noted in the published literature that several social partners with differing agendas are involved in shaping university education [2] [9] [52] and that a given social partner (e.g. the student) may play more than one role within various university activities [2]. An interesting model of this phe- 
nomenon and the associated interactions between social partners and the university has been proposed [53]. The definition of the client must be consistent with the role of the university, for example, preservation of the culture, scientific research and service to society in a communist country [45], creator and guardian of knowledge in British society [61].

The client has been defined as "an individual or group who has the power to specify and pay for services or products they want and value" [9]. Several models have been proposed to resolve the difficulty of defining such persons in the university setting: based on consideration of all stakeholders and their relative importance, using the quality triad concept to clarify the roles of stakeholder groups, considering future employers as clients and graduates as products, considering education as a service to students, based on three categories of classification (input clients, processed clients, output clients) or on two categories: primary and secondary clients depending on their position within or outside of the institution or on the frequency of their interactions with the institution [2] [60].

Many universities prefer to simplify the process of introducing the lean approach by focusing solely on the students [62]. This has had numerous documented consequences [59]. Among others, the student-client approach exposes faculty members and their support staff to increased OHS risks, especially psychosocial [63]. Others propose considering the students as collaborative partners on the same level as the other stakeholders, and reminding them of their responsibilities towards others as well as themselves [59] [64].

The notion of client thus seems to be a sensitive issue in the university setting, albeit one that has to be resolved adequately if efforts to improve processes are to be successful. One promising avenue appears to be identifying the key players in and end-users of each process under examination [28]. Defining quality in the university setting can become a difficult and perilous exercise [2] due to the complexities [65]. Several definitions have been proposed depending on the perspective [60] [65] [66]. Once the client is identified clearly, quality and added value are defined accordingly. While it is always necessary to remain aware of non-quality, over-quality is an equally problematic issue, one that was not broached in the literature examined.

\section{Conclusions}

This review summarizes the documented experiences (2000 to 2016) of universities with use of lean, six sigma and lean six sigma approaches to improve administrative efficiency and the overall quality of the education received by the students. We identified the goals of the interventions, universities particularly committed to applying this type of approach, the preferred tools, the findings (when presented), and the challenges encountered.

We have thus demonstrated the emergent character of the introduction of lean, six sigma and lean six-sigma philosophies into the university setting, as well as their rather localized deployment within the complex systems under ex- 
amination. Several challenges stand in the way of their successful application, including proper definition of the client, of added value and of the associations between teaching and research. Various avenues for resolving these difficulties have been proposed. The impact of such efforts, particularly with regard to OHS, is much less documented, which we regard as noteworthy, given that the impact of lean manufacturing on OHS, as described in the literature, may be positive or negative, due often to factors that remain to be identified. While approaches of this sort appear to hold promise, it is still too early to conclude that they will allow universities to gain a competitive advantage.

\section{References}

[1] Brookes, M. and Becket, N. (2007) Quality Management in Higher Education: A Review of International Issues and Practice. International Journal of Quality and Standards, 1, 1-37.

[2] Quinn, A., Lemay, G., Larsen, P. and Johnson, D.M. (2009) Service Quality in Higher Education. Total Quality Management, 20, 139-152. https://doi.org/10.1080/14783360802622805

[3] Comm, C.L. and Mathaisel, D.F.X. (2005) A Case Study in Applying Lean Sustainability Concepts to Universities. International Journal of Sustainability in Higher Education, 6, 134-146. https://doi.org/10.1108/14676370510589855

[4] Larouche, C. and Savard, D. (2012) Typologie des conceptions des universités en vue d'en évaluer la performance: Rendre compte de la diversité pour en saisir la complexité. Canadian Journal of Higher Education, 42, 45-64.

[5] Svensson, C., Antony, J., Ba-Essa, M., Bakhsh, M. and Albliwi, S. (2015) A Lean Six Sigma Program in Higher Education. International Journal of Quality \& Reliability Management, 32, 951-969. https://doi.org/10.1108/IJQRM-09-2014-0141

[6] Bandyopadhyah, J.K. and Lichman, R. (2007) Six Sigma Approach to Quality and Productivity Improvement in Institution for Higher Education in the United States. International Journal of Management, 24, 1-5.

[7] Brennan, L. and Bennington, L. (2000) Concepts in Conflict: Students and Customers-An Australian Perspective. Journal of Marketing for Higher Education, 9, 19 40. https://doi.org/10.1300/J050v09n02_02

[8] Hemsley-Brown, J.V. and Oplatka, I. (2006) Universities in a Competitive Global Marketplace: A Systematic Review of the Literature on Higher Education Marketing. International Journal of Public Sector Management, 19, 316-338. https://doi.org/10.1108/09513550610669176

[9] Watt, C., Angelis, J. and Chapman, D. (2012) Customer Value and Lean Operations in Masters Education. Proceedings of the 14th International Conference on Engineering and Product Design Education, Antwerp, 6-7th September 2012, 699-704.

[10] Vauterin, J.J., Linnanen, L. and Marttila, E. (2011) Issues of Delivering Quality Customer Service in a Higher Education Environment. International Journal of Quality and Service Sciences, 3, 181-198. https://doi.org/10.1108/17566691111146087

[11] Geryk, M. (2016) Global Challenges for the Universities and Managers of the Higher Education Sector. In: Kantola, J.J., et al., Eds., Advances in Human Factors, Business Management, Training and Education, Advances in Intelligent Systems and Computing, 455-464.

[12] Schalick, J.A. (2006) Technology and Changes in the Concept of the University: 
Comments on the Reinvention of the Role of the University East and West. PICMET 2006 Proceedings, Istanbul, 9-13 July 2006, 1140-1146. https://doi.org/10.1109/picmet.2006.296682

[13] Nejati, M. and Nejati, M. (2013) Assessment of Sustainable University Factors from the Perspective of University Studies. Journal of Cleaner Production, 48, 101-107.

[14] Hess, J.D. and Benjamin, B.A. (2015) Applying Lean Six Sigma within the University: Opportunities for Process Improvement and Cultural Change. International Journal of Lean Six Sigma, 3, 249-262. https://doi.org/10.1108/IJLSS-12-2014-0036

[15] Emiliani, M.L. (2015) Lean University. A Guide to Renewal and Prosperity. The CLBM, Wethersfield, $162 \mathrm{p}$.

[16] Suarez-Barraza, M.F., Smith, T. and Dahlgaard-Park, S.M. (2012) Lean Service: A Literature Analysis and Classification. Total Quality Management, 23, 359-380. https://doi.org/10.1080/14783363.2011.637777

[17] Francis, D.E. (2014) Lean and the Learning Organization in Higher Education. Canadian Journal of Educational Administration and Policy, No. 157, 1-23.

[18] Jordan, V. and Carruth, L. (2012) A Systems Approach to Implementing Systems Engineering within UT Health Institutions. Proceedings of the 2012 International Conference on Industrial Engineering and Operations Management, Istanbul, 3-6 July 2012, 646-655.

[19] Waterbury, T. (2015) Learning from Pioneers. A Multiple-Case Analysis of Implementing Lean in Higher Education. International Journal of Quality and Reliability Management, 32, 934-950. https://doi.org/10.1108/IJQRM-08-2014-0125

[20] Simons, N. (2013) The Business Case for Lean Six Sigma in Higher Education. ASQ Higher Education Brief, 6, 1-6.

[21] Albliwi, S., Antony, J., Halim Lim, S.A. and Von Der Wiele, T. (2014) Critical Failure Factors of Lean Six Sigma: a Systematic Literature Review. International Journal of Quality \& Reliability Management, 31, 1012-1030. https://doi.org/10.1108/IJQRM-09-2013-0147

[22] Radnor, Z. and Bucci, G. (2011) Analysis of Lean Implementation in UK Business Schools Universities. A to Z Business Consultancy, $74 \mathrm{p}$.

[23] Balzer, W.K. (2010) Lean Higher Education. Increasing the Value and Performance of University Processes. CRC Press, New York, 312 p. https://doi.org/10.1201/EBK1439814659

[24] Verma, A. and Crossman, G. (2006) An Assessment and Continuous Improvement Model for Engineering Technology Programs. ASEE Annual Conference and Exposition, Conference Proceedings American Society for Engineering Education, Chicago, June 2006, 11.172.2-11.176.11.

[25] Steinlicht, C., Neary, A., LeBrun, T., Sauke, K., Sundermann, C. and Weber, J. (2010) Program Development Work in Progress: Value Stream Mapping the Educational Process Outcomes. Frontiers in Education Conference, Washington DC, $27-$ 30 October 2010, T1H-1-T1H-2. https://doi.org/10.1109/fie.2010.5673395

[26] Emiliani, M.L. (2005) Using Kaizen to Improve Graduate Business School Degree Programs. Quality Assurance in Education, 13, 37-52. https://doi.org/10.1108/09684880510578641

[27] Djassemi, M. (2006) A Lean Approach to Manage a Capstone Senior Project Course. ASEE/IEE Frontiers in Education Conference, San Diego, 27-31 October 2006, 1-6. https://doi.org/10.1109/fie.2006.322290

[28] Doman, M.S. (2011) A New Lean Paradigm in Higher Education: a Case Study. Quality Assurance in Education, 19, 248-262. 
https://doi.org/10.1108/09684881111158054

[29] Emiliani, M.L. (2004) Improving Business School Courses by Applying Lean Principles and Practices. Quality Assurance in Education, 12, 175-187.

https://doi.org/10.1108/09684880410561596

[30] Nuno, P., Lopez-Molina, M.G. and Reyes-Guerra, B. (2010) A Lean Management Model and a Case Study in Mexico. Proceedings of the 2010 Industrial Engineering Research Conference, Cancun, 6-9 June 2010, 1-6.

[31] Simmons, D.R. and Young, G. (2014) Improving the Student Academic Experience through Lean Engineering Principles. Frontiers in Education Conference, 22-25 October 2014, 1-4. https://doi.org/10.1109/fie.2014.7044326

[32] Thirkell, E. and Ashman, I. (2014) Lean towards Learning: Connecting Lean Thinking and Human Resource Management in UK Higher Education. The International Journal of Human Resource Management, 25, 2957-2977. https://doi.org/10.1080/09585192.2014.948901

[33] Hines, P. and Lethbridge, S. (2008) New Development: Creating a Lean University. Public Money and Management, 28, 53-56.

[34] Kettunen, J. (2011) External and Internal Quality Audits in Higher Education. The TQM Journal, 26, 518-528.

[35] Kruger, D. (2015) Process Integration and Improvement in a Higher Education Institution in South Africa. Proceedings of PICMET15: Management of the Technology Age, Portland, 2-6 August 2015, 1424-1432.

[36] Kholopane, P. and Vandayar, C. (2014) Lean Application in Student Finance Department within a Learning Institution Can Lead to High Academic Throughput: A Case Study. Proceedings of PICMET 14: Infrastructure and Service Integration, Kanazawa, 27-31 July 2014, 988-994.

[37] Sinha, P. and Mishra, N.M. (2013) Applying Lean Thinking to Higher EducationA Strategy for Academic Excellence. Indian Journal of Applied Research, 3, 1-4. https://doi.org/10.15373/2249555X/OCT2013/80

[38] Burge III, L., Garuba, M. and Brent, C. (2004) Improving Retention of Minority Freshman in Engineering by Applying the Six Sigma Methodology. Proceedings of the International Conference on Information Technology: Coding and Computing, Las Vegas, 5-7 April 2004, 723-728.

[39] Chow, T. and Downing, C. (2016) Adapting Six Sigma for Academia. ISE Magazine, 48, 24-29.

[40] Hargrove, S.K. and Burge, L. (2002) Developing a Six Sigma Methodology for Improving Retention in Engineering Education. 32nd ASEE/IEEE Frontiers in Education Conference, Boston, 6-9 November 2002, S3C-20-S3C-24.

[41] Verma, A. (2008) Applying Six Sigma Methodology to the Admissions Process in Higher Education. ASEE Annual Conference and Exposition, Conference Proceedings, Pittsburgh, 22-25 June 2008, 13.215.1-13.215.13.

[42] Kaushik, K. and Khanduja, D. (2010) Utilising Six Sigma for Improving Pass Percentage of Students: A Technical Institute Case Study. Educational Research and Review, 5, 471-483.

[43] Prasad, K.G.D., Subbaiah, K.V. and Padmavathi, G. (2012) Application of Six Sigma Methodology in an Engineering Educational Institution. International Journal of Emerging Sciences, 2, 222-237.

[44] Tenali, S., Ganti, R.S. and Taranikanth, K. (2015) Implementing Lean Six Sigma to Improve the Ratio of Admissions to Placements in an Academic Year: Statistical and Psychological Case Study of a Technical Institute. Proceedings of the 2015 In- 
ternational Conference on Industrial Engineering and Operations Management, Dubai, 3-5 March 2015, 1-12. https://doi.org/10.1109/IEOM.2015.7093738

[45] Zhao, L. (2011) China's Higher Education Quality Management Based on Six-Sigma Management Principles. International Conference on Artificial Intelligence, Management Science and Electronic Commerce, Deng Leng, 8-10 August 2011, 65596561.

[46] Coowar, R., Furterer, S., Akinrefon, T., Battikhi, A., Ferreras, A., Gibson, K., Lakkoju, R. and Meza, K. (2006) Lean Six Sigma as an Improvement Tool in Academia. ASEE Annual Conference and Exposition, Conference Proceedings American Society for Engineering Education, Chicago, June 2006, 11.867.1-11.867.19.

[47] Raifsnider, R. and Kurt, D. (2004) Lean Six Sigma in Higher Education: Applying Proven Methodologies to Improve Quality, Remove Waste, and Quantify Opportunities in Colleges and Universities. Xerox White Paper, $10 \mathrm{p}$.

[48] Kanakana, M.G., Pretorius, J.H.C. and Van Wyk, B. (2010) Lean Six Sigma Framework to Improve Throughput Rate. 17th International Conference on Industrial Engineering and Engineering Management, Xiamen, 29-31 October 2010, 862-866. https://doi.org/10.1109/icieem.2010.5646488

[49] Comm, C.L. and Mathaisel, D.F.X. (2005) An Exploratory Study of Best Lean Sustainability Practices in Higher Education. Quality Assurance in Education, 13, 227 240. https://doi.org/10.1108/09684880510607963

[50] Ho, S.L., Xie, M. and Goh, T.N. (2006) Adopting Six Sigma in Higher Education: Some Issues and Challenges. International Journal of Six Sigma and Competitive Advantage, 2, 335-352. https://doi.org/10.1504/IJSSCA.2006.011564

[51] Antony, J., Krishan, N., Cullen, D. and Kumar, M. (2012) Lean Six Sigma for Higher Education Institutions (HEIs). Challenges, Barriers, Success Factors, Tools/Techniques. International Journal of Productivity and Performance Management, 61, 940-948. https://doi.org/10.1108/17410401211277165

[52] Eagle, L. and Brennan, R. (2007) Are Students Customers? TQM and Marketing Perspectives. Quality Assurance in Education, 15, 44-60. https://doi.org/10.1108/09684880710723025

[53] Houston, D. (2008) Rethinking Quality and Improvement in Higher Education. Quality Assurance in Education, 16, 61-79. https://doi.org/10.1108/09684880810848413

[54] Thomas, A.J., Antony, J., Francis, M. and Fisher, R. (2015) A Comparative Study of Lean Implementation in Higher and Further Education Institutions in the UK. International Journal of Quality and Reliability Management, 32, 982-996. https://doi.org/10.1108/IJQRM-09-2014-0134

[55] Nalebuff, B. and Brandenburger, A. (1996) La Co-opétition. Une révolution dans la manière de jouer concurrence et coopération. Village Mondial, Paris, $306 \mathrm{p}$.

[56] Porter, M.E. (1980) Competitive Strategy. Techniques for Analyzing Industries and Competitors. Free Press, New York, $432 \mathrm{p}$.

[57] Porter, M.E. (1985) Competitive Advantage. Creating and Sustaining Superior Performance. Free Press, New York, 557 p.

[58] Wiklund, H., Klefsjö, B., Wiklund, P.S. and Edvardsson, B. (2003) Innovation and TQM in Swedish Higher Education Institutions-Possibilities and Pitfalls. The TQM Magazine, 15, 99-107. https://doi.org/10.1108/09544780310461116

[59] Clayson, D.E. and Haley, D.A. (2005) Marketing Models in Education: Students as Customers, Products, or Partners. Marketing Education Review, 15, 1-10. https://doi.org/10.1080/10528008.2005.11488884 
[60] Sahney, S., Banwet, D.K. and Karunes, S. (2004) A SERVQUAL and QFD Approach to Total Quality Education. A Student Perspective. International Journal of Productive and Performance Management, 53, 143-166. https://doi.org/10.1108/17410400410515043

[61] Cranfield, D.J. and Taylor, J. (2008) Knowledge Management and Higher Education: A UK Case Study. The Electronic Journal of Knowledge Management, 6, 85100.

[62] El-Sayed, M., Zgorzelski, M., Berry, K.J. and Zang, P.H. (2005) Lean Thinking and Quality Control Strategies for Improving Engineering Educational Processes. ASEE Annual Conference and Exposition, Conference Proceedings American Society for Engineering Education, Portland, June 12-15 2005, 10.871.1-10.871.7.

[63] Leclerc, C. and Bourassa, B. (2013) Travail professoral et santé psychologique. Centre de recherche et d'intervention sur l'éducation et la vie au travail. Université Laval, 278 p.

[64] Bay, D. and Daniel, H. (2001) The Student Is Not the Customer-An Alternative Perspective. Journal of Marketing for Higher Education, 11, 1-19. https://doi.org/10.1300/J050v11n01_01

[65] Voss, R., Gruber, T. and Szmigin, I. (2007) Service Quality in Higher Education: The Role of Student Expectations. Journal of Business Research, 60, 949-959.

[66] Dew, J. (2009) Quality Issues in Higher Education. The Journal for Quality and Participation, 32, 4-9.

Submit or recommend next manuscript to SCIRP and we will provide best service for you:

Accepting pre-submission inquiries through Email, Facebook, LinkedIn, Twitter, etc. A wide selection of journals (inclusive of 9 subjects, more than 200 journals)

Providing 24-hour high-quality service

User-friendly online submission system

Fair and swift peer-review system

Efficient typesetting and proofreading procedure

Display of the result of downloads and visits, as well as the number of cited articles

Maximum dissemination of your research work

Submit your manuscript at: http://papersubmission.scirp.org/

Or contact ajibm@scirp.org 